Proc. Estonian Acad. Sci. Geol., 2000, 49, 2, 69-84

\title{
THE SILURIAN OF THE TIMAN-NORTHERN URAL REGION
}

\author{
Anna I. ANTOSHKINA
}

Institute of Geology, Komi Science Centre, Uralian Division of the Russian Academy of Sciences, Pervomajskaya 54, 167982 Syktyvkar, Komi Republic, Russia; Antoshkina@ geo.komisc.ru

Received 25 October 1999, in revised form 7 February 2000

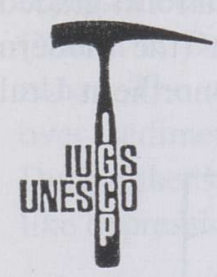

IGCP Project 406

Circum-Arctic Lower-

Middle Palaeozoic

Vertebrate Palaeontology

and Biostratigraphy

Abstract. During the Silurian, an extensive carbonate platform formed on the northeastern continental shelf of Baltica. The sediments on it are represented by lagoonal, reef, backreef, restricted shelf, and open shelf facies and, as a rule, are highly fossiliferous.

Three events affected strongly the pattern of sedimentation in the region. First, at the end of the Ordovician, glacioeustatic sea level lowering drained the platform and sedimentation ceased on most of it. Rapid glacial melting, accompanied by a sea level rise in the early Silurian (Yarenej time), returned deposition to the platform. Second, in

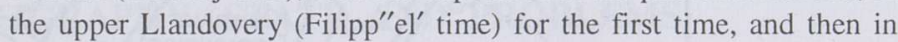
the Wenlock (Ust'Durnayu time) and Ludlow (Padimejtyvis and Sizim times), the east-dipping ramp was converted to a rimmed shelf with reefs on its outer margin, and with slumps, debris-flows, and turbidites on the newly formed slope. The third major event in the basin history was a gradual regression which began in the late Silurian and culminated in the Early Devonian. The sea level fluctuations determined in the Silurian of the Timan-northern Ural region well correlate with the global eustatic curve.

Key words: facies, stratigraphy, palaeogeography, Silurian, Timan-northern Ural region, Russia.

\section{INTRODUCTION}

During Silurian time the Timan-northern Ural region was located in low latitudes of the Northern Hemisphere (Zonenshain et al. 1990). Sedimentation took place on an extensive carbonate platform, generally under the conditions of a gradually subsiding continental margin. The Silurian Timan-northern Ural epicontinental sea was shallow, basically with a flat bottom sloping very gently to the east, towards the Uralian ocean. Tidal flat, lagoonal, shoal, and shallow shelf environments with characteristic communities of biota dominated in this basin 
(Filippova 1973; Antoshkina et al. 1976; Antoshkina \& Beznosova 1987). The Silurian shelf carbonates which formed a laterally continuous facies tract appear to have been principally constructed by benthic microbial and metazoan communities. Periodically, these carbonates developed into reef barriers restricting the shelf circulation and initiating, in some cases, sedimentation of lagoonal evaporites. The occurrence of black graptolitic shales (so-called Lemva Facies) on the western slope of the Urals indicates that anoxic conditions developed along the continental shelf margin (Vojnovskij-Kriger 1945; Koren 1964).

\section{GEOLOGICAL SETTING}

The Timan-northern Ural region represents the northeastern part of the East European Platform, the so-called Pechora Plate. It extends from the Timan Ridge in the west to the western part of the Northern, Polar, and Subpolar Urals in the east (Fig. 1). During the Silurian, an eastwards-facing carbonate platform graded into a basin which was surrounded by an island arc in the east (the modern eastern slope of the Urals). The easternmost zone of the Timan-northern Ural

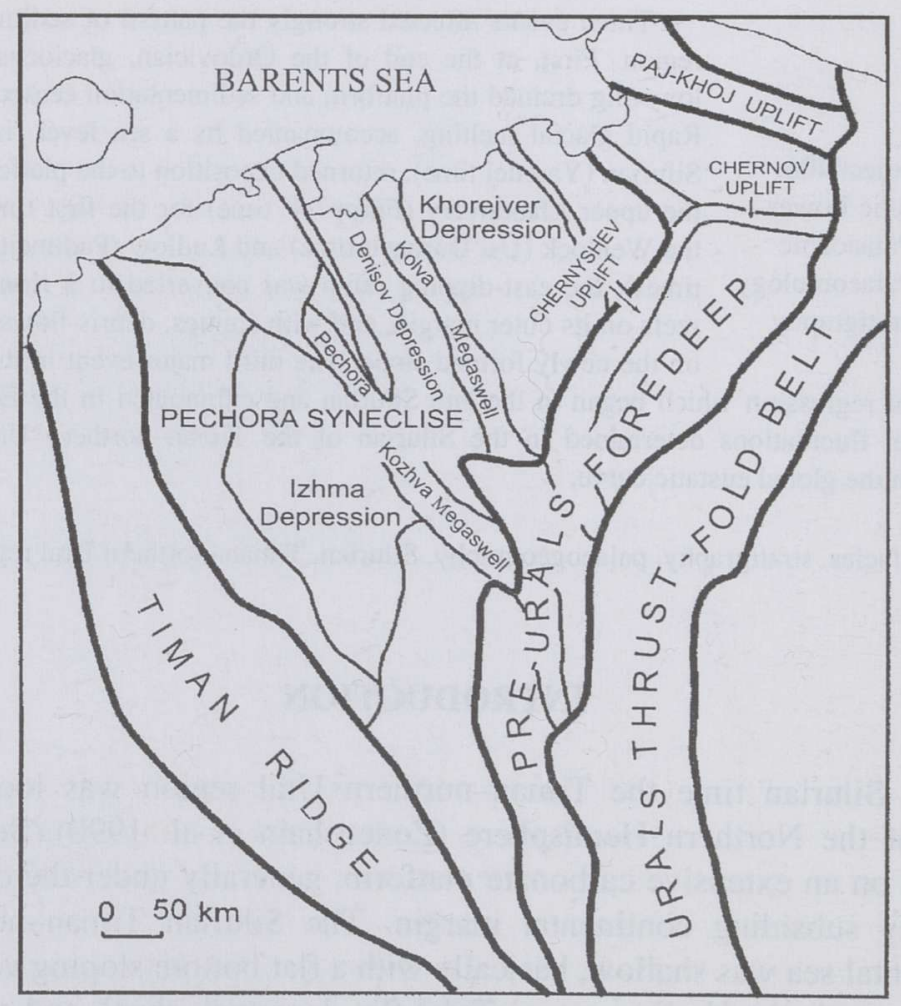

Fig. 1. Schematic structural map of the Pechora Plate. 
region coincides with the Pechora Urals, representing the northern part of the western structural zone of the Ural Mountains. It forms a complexly dislocated eastern margin (pericratonic subsidence) of the Pechora Plate. Considerable deformation resulted from the westwards-directed emplacement of a thrust zone which started in the eastern part of the Urals in the late Silurian-Early Devonian, and from the obduction of the oceanic crust on, and accretion of island arcs or microcontinents to the north and northeastern Baltica during the final closing of the Uralian ocean later in the Palaeozoic (Puchkov 1993; Savelieva \& Nesbitt 1996). Westwards, the Pechora Urals are separated from the Pre-Urals Foredeep by the Major West-Urals Thrust. In the west, the Pre-Urals Foredeep borders the Pechora Syneclise. From the Ordovician to Lower Devonian, the evolution of the Timan-northern Ural sedimentary basin was closely related to the development of the Uralian palaeocean, under geodynamic conditions responsible for a passive margin, intraplate depressions and uplifts, and a foredeep. Their structural plan mainly inherited the landscape of the Riphean basement. The palaeostructure was represented by a SE-NW trending chain of troughs and trough-like depressions (Yudin \& Dedeev 1987). These troughs were bound by rather elevated transfer zones. The morphology of the troughs and transfer zones was the main control over sedimentation within the Timan-northern Ural basin (Malyshev 1994). During the Silurian, the thickest strata of clay carbonates deposited in the troughlike depressions of the modern south Kolva Megaswell.

\section{STRATIGRAPHY: STATE AND PROBLEMS}

The foundation to our understanding of the Silurian stratigraphy in the northeastern part of the East European Platform was laid by A. I. Pershina (Pershina 1962; Pershina et al. 1971). Geological studies of the last decades have revealed a great similarity of the shelf carbonate deposits in the Pechora Syneclise with those in the Pre-Urals Foredeep and Pechora Urals. The first Silurian stratigraphic scheme of the Timan-Pechora region was accepted in Tallinn in 1984, at the Interdepartmental Stratigraphic Meeting on the Ordovician and Silurian of the East European Platform (Kaljo 1987).

The best known sequence of Silurian carbonates, about $1300 \mathrm{~m}$ thick, is exposed in the Subpolar Urals, on the Kozhym River. Here, the full set of highly fossiliferous shelf carbonate facies - lagoonal, reef, backreef, restricted shelf, and open shelf - can be studied. The section on the Kozhym River was proposed as the standard for the Silurian sequence in the Timan-Pechora province and on the western slope of the Urals (Tsyganko \& Chermnykh 1983, 1987; Nestor 1987; Antsygin et al. 1993). Detailed study of the Silurian strata in the Kozhym River section has promoted a significant advance in the stratigraphy of the described region. At present, nine formations are recognized in the Silurian sequence in the Pechora Urals and Pre-Urals Foredeep (Antoshkina et al. 1989). The lower seven 
were introduced as stages in the unified part of the stratigraphic schemes of the western Urals in 1993 (Fig. 2). The type sections of the regional stages corresponding to the Ludlow Series are located in the Chernov Uplift and of those corresponding to the Pridoli Series - on Vajgach Island. In the Subpolar Urals, the parastratotypes of these stages are defined in the Kozhym River section. Detailed lithological study of the Chernyshev, Chernov, and Uralian sections is essential to the solution of several stratigraphic problems, including the positions of the Ordovician-Silurian, Llandovery-Wenlock, and Silurian-Devonian boundaries in the Timan-northern Ural region.

Ordovician-Silurian boundary. The position of the Ordovician-Silurian boundary proposed in the stratigraphic scheme of the Timan-Pechora region is based on data from a well-log and is considered to correspond to the contact between the carbonates of the Yaptikshor (in the Urals) or Salyuka (in the Pechora Syneclise) formations and the carbonate-evaporate-terrigenous strata of the underlying Khorejver Formation (Kaljo 1987). However, this level does not agree with new palaeontological and sedimentological data. Abrupt replacement of the late Ashgill Proconchidium-Holorhynchus brachiopod and Aphelognathus-Belodina conodont assemblages (occurring in the Yaptikshor and Salyuka formations) by the early Llandovery Virgiana brachiopod and Distomodus-Ozarkodina conodont faunas (known from the Yarenej Formation) is observed within the lithologically quite homogeneous secondary organogenic dolostones. Formerly, the Yaptikshor, Yarenej, and Lolashor formations have also been described as corresponding to the "Adak Series" (Antoshkina et al. 1989).

In some sections rather sharp lithological changes take place at the Ordovician-Silurian boundary. In the Kozhym River section, the upper Ashgill light grey upper-subtidal dolomitized limestones, containing the brachiopods Holorhynchus, tabulate coral Eocatenipora, and rugose coral Palaeophyllum, are overlain by black deep-water shelf dolomitized limestones of early Llandovery age (Antoshkina 1988). Crinoid debris, rare specimens of the tabulate coral Mesofavosites, and interbeds with abundant radiolarians and spicules are common. In the Chernyshev Uplift on the Usa and Malyj Adak rivers, the up to $70 \mathrm{~m}$ thick Ordovician-Silurian boundary beds are represented by claystones, lumpy-bedded limestones, and secondary dolostones. They are characterized by benthic communities containing the late Ashgill brachiopod Holorhynchus, rugose coral Palaeophyllum, tabulate coral Agetolites, conodont Belodina, and some endemic Llandovery brachiopods - Protatrypa, Nalivkinia, Pseudocamarotoechia, Idiospira, Virgiana (Beznosova 1985; Antoshkina \& Beznosova 1987). Probably these beds represent the youngest part of the Ashgill sequence preserved in the Timan-northern Ural region. In most areas, these strata were destroyed by pre-Silurian erosion caused by the final stage of late Ordovician glaciation. In the southwestern part of the Khorejver Depression (borehole Vostochnyj Vozej 1), the position of the Ordovician-Silurian boundary can be 


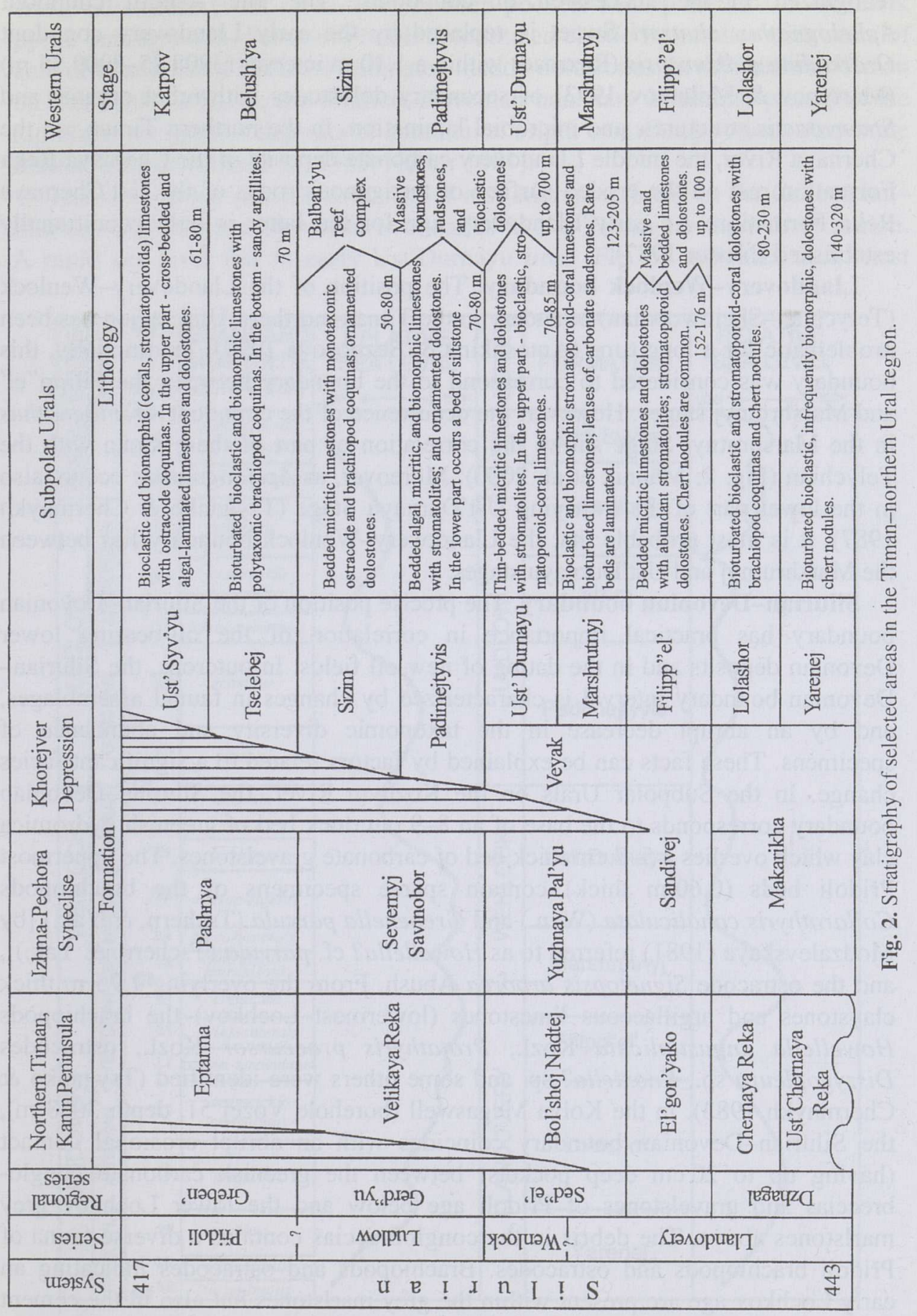


recognized in the succession of conodonts. The late Ashgill conodont Aphelognathus shatzeri Sweet is replaced by the early Llandovery conodont Ozarkodina oldhamensis (Rexroad) within a 1.10 m interval (3908.25-3909.35 m) (Martynov \& Melnikov 1993) of secondary dolostones with relict organic and Stromatactis structures, and microbial lamination. In the northern Timan, on the Chernaya River, the middle Llandovery carbonate deposits of the Chernaya Reka Formation rest on the eroded surface of terrigenous rocks of the Ust'Chernaya Reka Formation. An early Llandovery age for the latter is only conditionally established (Nestor 1987).

Llandovery-Wenlock boundary. The position of the Llandovery-Wenlock (Telychian-Sheinwoodian) boundary in the Timan-northern Ural region has been problematic for a long time (Antoshkina \& Beznosova 1999). Traditionally, this boundary was considered to correspond to the boundary between the Filipp"el' and Marshrutnyj stages. However, the occurrence of the conodont Apsidognathus in the Marshrutnyj Stage shows the correlation of part of these strata with the Telychian (Fig. 2; Männik et al. 2000). Moreover, as Apsidognathus occurs also in the lower part of the overlying Ust'Durnayu Stage (Tsyganko \& Chermnykh 1987), it is most probable that the Llandovery-Wenlock boundary lies between the Marshrutnyj and Ust'Durnayu stages.

Silurian-Devonian boundary. The precise position of the Silurian-Devonian boundary has practical importance in correlation of the oil-bearing lower Devonian deposits and in the dating of new oil fields. In outcrops, the SilurianDevonian boundary interval is characterized by changes in faunal assemblages, and by an abrupt decrease in the taxonomic diversity and abundance of specimens. These facts can be explained by factors related to a significant facies change. In the Subpolar Urals on the Kozhym River, the Silurian-Devonian boundary corresponds to the base of an $8-9 \mathrm{~cm}$ thick bed of greenish hydromica clay which overlies a 5-7 cm thick bed of carbonate gravelstones. The uppermost Pridoli beds $(0.60 \mathrm{~m}$ thick) contain sparse specimens of the brachiopods Collarothyris canaliculata (Wen.) and Grebenella parvula (Tschern. \& Yak.) [by Modzalevskaya (1981) referred to as Howellella? cf. parvula (Tschern. \& Yak.)], and the ostracode Signetopsis arborea Abush. From the overlying $1.75 \mathrm{~m}$ thick claystones and argillaceous limestones (lowermost Lochkov) the brachiopods Howellella angustiplicata Kozl., Protathyris praecursor Kozl., ostracodes Diszygopleura sp., Knoxiella? sp. and some others were identified (Tsyganko \& Chermnykh 1983). In the Kolva Megaswell (borehole Vozej 51, depth 3088 m), the Silurian-Devonian boundary coincides with an abrupt erosional contact (having up to $20 \mathrm{~cm}$ deep pockets) between the greenish carbonate conglobreccias and gravelstones of Přidoli age below and the lower Lochkov grey marlstones above. The debris in the conglobreccias contains a diverse fauna of Přidoli brachiopods and ostracodes. Brachiopods and ostracodes indicating an early Lochkov age are present within the grey marlstones but also in the cement of the conglobreccias. In the. Khorejver Depression (borehole Varknavtskaya 23, depth $4290.6 \mathrm{~m}$ ), the Silurian-Devonian boundary is characterized by an 
erosional surface (with up to 5-7 $\mathrm{cm}$ deep pockets and up to $0.2-0.3 \mathrm{~cm}$ thick pyrite impregnation) between Pridoli dolomitized clastic limestones with nests of anhydrite and lower Lochkov laminated muddy dolostones. In the northern Timan on the Velikaya River, the Silurian-Devonian boundary is usually placed at the top of the terrigenous deposits of continental origin containing various vertebrate fossils (Valiukevičius et al. 1983; Nestor 1987).

The facts above provide evidence of a stratigraphic break at the OrdovicianSilurian and Silurian-Devonian boundaries in the Timan-northern Ural region. A rapid sea level fall in early Ust'Durnayu time (Fig. 3) indicates that, most

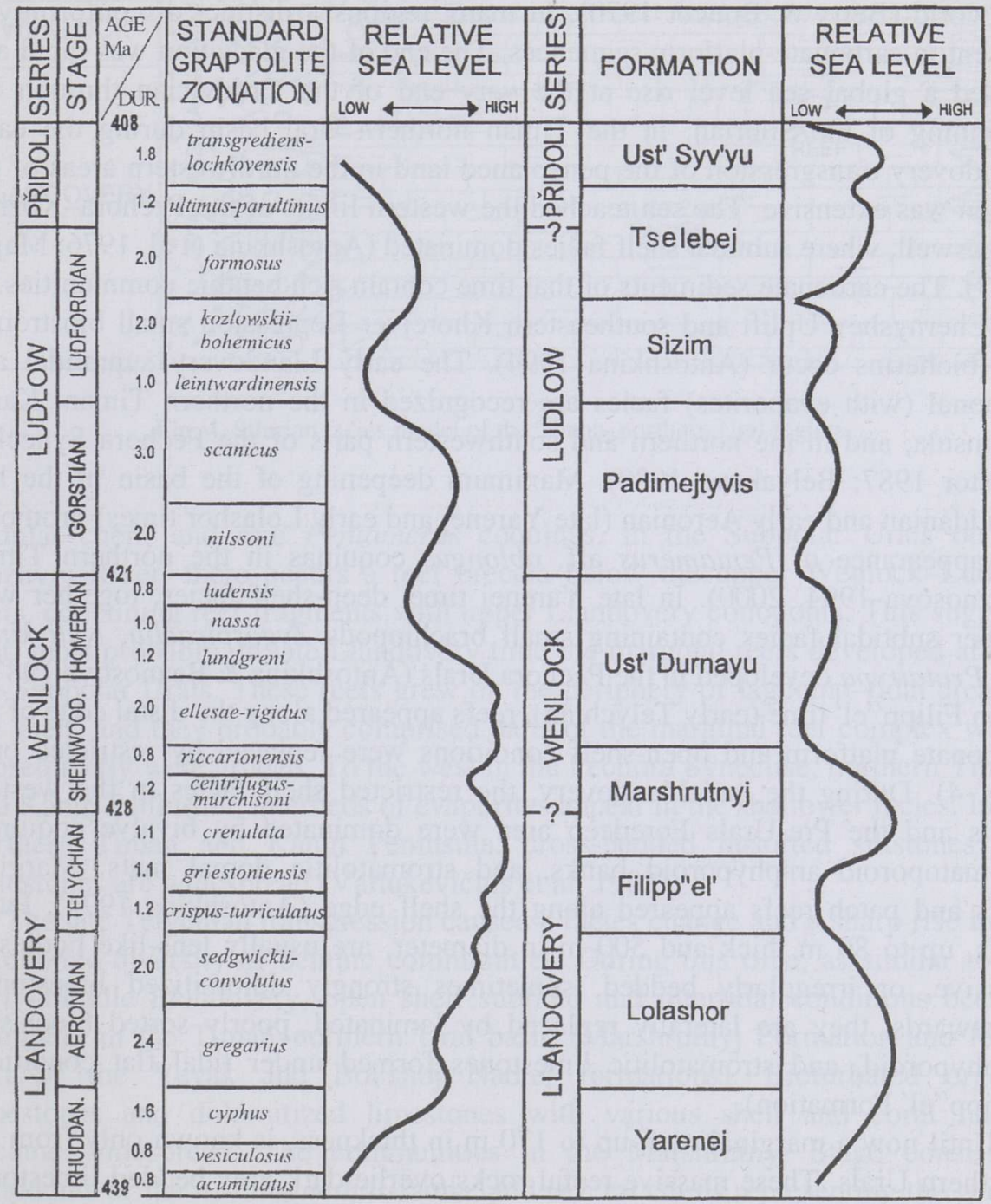

Fig. 3. Correlation of the Silurian sea level curve of the Timan-northern Ural region (right) with the global one by Johnson et al. (1991). 
probably, sedimentation was not continuous also in the Llandovery-Wenlock boundary interval. The duration of hiatuses varies from area to area. The formation of gaps in sedimentation and their varied duration in different areas were caused by a general eustatic fall in sea level but were also influenced by regional tectonic movements.

\section{PALAEOGEOGRAPHY}

The late Ashgill Gondwana glaciation drained epicontinental seas around the world (Berry \& Boucot 1970). In many regions a distinct disconformity is present in carbonate-platform sequences. The end of the glaciation was rapid and caused a global sea level rise at the very end of the Ordovician through the beginning of the Silurian. In the Timan-northern Ural basin during the early Llandovery transgression of the peneplaned land in the northwestern areas of the region was extensive. The sea reached the western limits of the Pechora-Kozhva Megaswell, where subtidal shelf facies dominated (Antoshkina et al. 1976; Majdl' 1987). The carbonate sediments of that time contain rich benthic communities. In the Chernyshev Uplift and southeastern Khorejver Depression small biostromes and bioherms occur (Antoshkina 1994). The early Llandovery supratidal and lagoonal (with evaporites) facies are recognized in the northern Timan, Kanin Peninsula, and in the northern and southwestern parts of the Pechora Syneclise (Nestor 1987; Belyakova 1988). Maximum deepening of the basin in the late Rhuddanian and early Aeronian (late Yarenej and early Lolashor times) promoted the appearance of Pentamerus aff. oblongus coquinas in the northern Timan (Beznosova 1994, 2000). In late Yarenej time, deep-shelf facies, together with deeper subtidal facies containing small brachiopods Zygospiraella, Nalivkinia, and Protatrypa developed in the Pechora Urals (Antoshkina \& Beznosova 1987).

In Filipp"el' time (early Telychian), reefs appeared along the distal edge of the carbonate platform and open-shelf conditions were replaced by restricted ones (Fig. 4). During the late Llandovery, the restricted shelf facies in the western Urals and the Pre-Urals Foredeep area were dominated by bivalve coquinas, stromatoporoid-amphyporoid banks, and stromatolitic domal mats. Marginal reefs and patch reefs appeared along the shelf edge (Antoshkina 1994). Patch reefs, up to $80 \mathrm{~m}$ thick and $500 \mathrm{~m}$ in diameter, are usually lens-like bodies of massive, or irregularly bedded, sometimes strongly dolomitized limestones. Westwards, they are laterally replaced by laminated, poorly sorted bioclastic, amphyporoid, and stromatolitic limestones formed under tidal flat conditions (Filipp"el' Formation).

Until now a marginal reef, up to $170 \mathrm{~m}$ in thickness, is known only from the Northern Urals. These massive reefal rocks overlie dark grey bedded limestones which accumulated in rather deep-water environments on a gentle platform slope. The strata immediately underlying the reefs are rich in fine skeletal debris, 


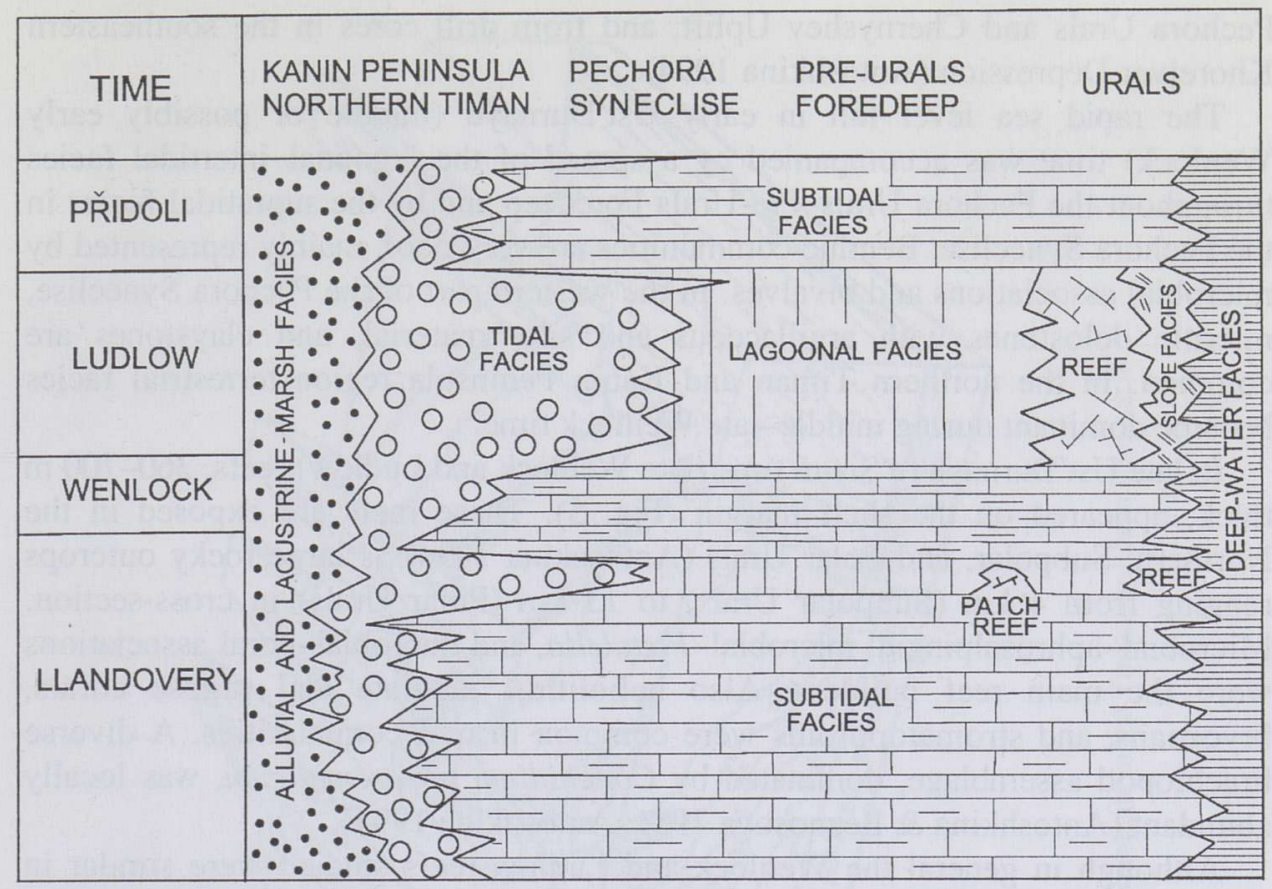

Fig. 4. Silurian facies model of the Timan-northern Ural region.

nodular chert, and rare Pentamerus coquinas. In the Subpolar Urals on the Kozhym River, there occurs a reef breccia below the upper Wenlock-Ludlow reefs, containing reef fragments with upper Llandovery conodonts. This suggests that, most probably, in late Llandovery time the marginal reefs developed also in the Subpolar Urals. These reefs grew on the periphery of lagoonal-tidal areas of the shelf, and they probably comprised parts of the marginal reef complex which subsequently were eroded. To the west in the Pechora Syneclise, northern Timan, and Kanin Peninsula, interbeds of evaporites appear in the shallower facies. In the northern Timan and Kanin Peninsula, cross-bedded unsorted siltstones and sandstones are widespread (Valiukevičius et al. 1983).

The late Telychian transgression caused a facies change and a sharp rise in the taxonomic diversity of benthic communities. During this time, as similar to the early-middle Llandovery, open shelf subtidal and intertidal conditions became dominant in the Timan-northern Ural basin (Marshrutnyj Formation and lower part of the Veyak and Bol'shoj Nadtej formations). Bioturbated organic limestones and dolomitized limestones with various shell and coral faunas became widespread. The communities in the Marshrutnyj Stage consist of conodonts of the Apsidognathus-fauna, and several corals representing the genera Favosites and Multisolenia (Nestor 1987; Antoshkina et al. 1989). Coralstromatoporoid and stromatoporoid biostromes and bioherms are known in the 
Pechora Urals and Chernyshev Uplift, and from drill cores in the southeastern Khorejver Depression (Antoshkina 1994).

The rapid sea level fall in early Ust'Durnayu (middle or possibly early Wenlock) time was accompanied by a spread of the lagoonal-intertidal facies throughout the Pechora Urals-Pre-Urals Foredeep and by the supratidal facies in the Pechora Syneclise. Benthic communities are very poor, mainly represented by microbial associations and bivalves. In the western part of the Pechora Syneclise, micritic dolostones with argillaceous and silty material, and claystones are common. In the northern Timan and Kanin Peninsula region terrestrial facies became dominant during middle-late Wenlock time.

In late Ust'Durnayu to Sizim time (late Wenlock and Ludlow) reefs, 360-700 m thick, appeared on the shelf margin (Fig. 5). These reefs are exposed in the Northern, Subpolar, and Polar Urals (Antoshkina 1994) as large rocky outcrops ranging from $4 \mathrm{~km}$ (Subpolar Urals) to $13 \mathrm{~km}$ (Polar Urals) in cross-section. Microbial-aphrosalpingid, microbial-Fistulella, and microbial-coral associations were the main reef builders. Also heliolitids, tabulate and rugose corals, bryozoans, and stromatoporoids were common in reef communities. A diverse brachiopod assemblage, dominated by Conchidium novosemelicum, was locally abundant (Antoshkina \& Beznosova 1981; Antoshkina 1994).

Although in general the Wenlock and Ludlow reefs studied were similar in composition, the following major differences could be noticed:

1) Main metazoan reef builders, and their size. Sphinctozoan aphrosalpingid sponges, widespread in the reefs of the Northern Urals, have not been recorded in the Subpolar and Polar Urals. The problematic hydroid Fistulella predominates in the reefs of the Polar Urals while the colonial rugose corals Zelophyllum, Holacantia, Pseudoamplexus, Pseudomicroplasta, and the tabulate corals Halysites and Syringopora dominate in the Subpolar Urals (Antoshkina 1994).

2) History of reef development. In the Northern Urals, the late Wenlock was characterized by microbial mounds. Here, mature reefs appeared not before the Ludlow, whereas in the Subpolar Urals mature reefs started to grow already in late Wenlock time. The reefs are underlain by sediments which are interpreted as being formed along the shelf margin by submarine canyon currents during late Llandovery-Wenlock time (Antoshkina 1994). Also in the Polar Urals mature reefs appeared only in Ludlow time (Fig. 4).

3) Thickness of reefs.

4) Geometry of the reef growth pattern. The late Wenlock-Ludlow reefs have a compound shape in the Northern Urals, aggrading shape in the Subpolar Urals, and prograding shape in the Polar Urals. In the Northern Urals reefs grew during the phase of instable subsidence of the shelf margin, interrupted by temporary stable periods in the course of which abundant flank deposits accumulated. The thickest reef in the Subpolar Urals formed during compensated stable subsidence when the conditions were evidently most favourable for reef building and the aggradational growth pattern developed. The thinnest reef in the Polar Urals was formed in response to the gradual uplift of the shelf margin. The uplift of the 


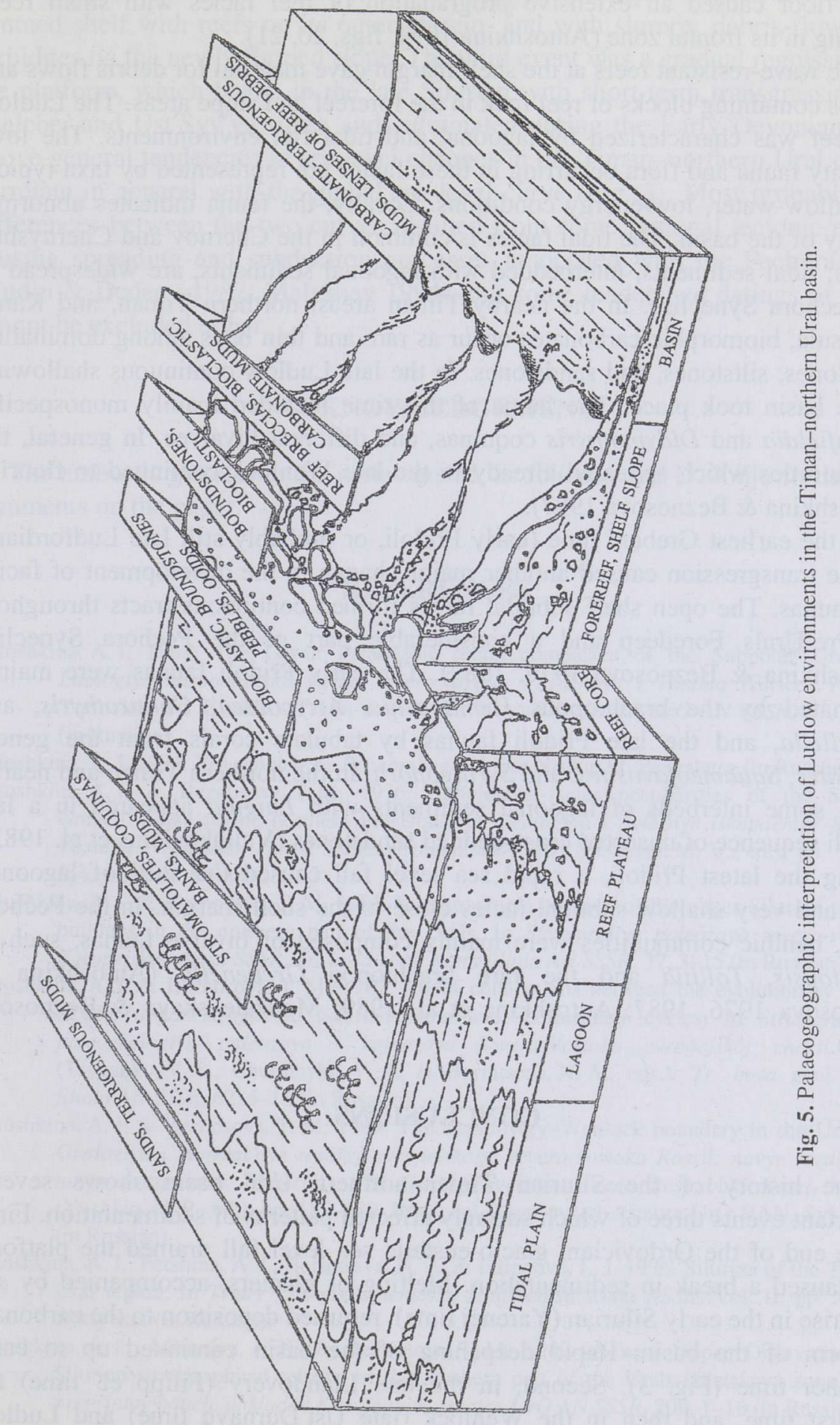


basin floor caused an extensive progradation of reef facies with small reefs growing in its frontal zone (Antoshkina 1994, figs. 20, 21).

The wave-resistant reefs at the shelf margin gave material for debris flows and slumps containing blocks of reef rock in the forereef and slope areas. The Ludlow backreef was characterized by lagoonal and tidal flat environments. The lowdiversity fauna and flora occurring in these facies are represented by taxa typical of shallow-water, low-energy conditions. Locally, the fauna indicates abnormal salinity of the basin. The tidal facies is common in the Chernov and Chernyshev uplifts; tidal sediments, interbedded with lagoonal sediments, are widespread in the Pechora Syneclise. In the nearby Timan areas, northern Timan, and Kanin Peninsula, biomorphic carbonates occur as rare and thin beds among dominating mudstones, siltstones, and sandstones. In the late Ludlow continuous shallowing of the basin took place. The fauna of this time included mainly monospecific Greenfieldia and Didymothyris coquinas, and different bivalves. In general, the communities which appeared already in the late Wenlock continued to flourish (Antoshkina \& Beznosova 1987).

In the earliest Greben' time (early Prridoli, or probably still late Ludfordian), marine transgression caused another major change in the development of facies and faunas. The open shelf subtidal facies formed continuous tracts throughout the Pre-Urals Foredeep and a considerable part of the Pechora Syneclise (Antoshkina \& Beznosova 1976, 1987). The early Přidoli faunas were mainly dominated by the brachiopods Hemitoechia, Atrypoidea, Collarothyris, and Howellella, and the late Pridoli faunas by tabulate corals from the genera Favosites, Squameofavosites, and Syringopora. In the northern Timan and nearby areas, some interbeds of lagoonal sediments with Lingula appeared in a late Přidoli sequence of unsorted cross-bedded sandstones (Valiukevičius et al. 1983). During the latest Prridoli, a rapid sea level fall caused the shift of lagoonal, tidal, and very shallow subtidal facies close to the shelf margin. In the Pechora Urals, benthic communities were mainly composed of bivalve faunas, such as Signetopsis, Tollitia and the rare brachiopod Grebenella (Antoshkina \& Beznosova 1976, 1987; Antoshkina et al. 1989; Modzalevskaya \& Beznosova 1992).

\section{CONCLUSIONS}

The history of the Silurian Timan-northern Ural basin shows several important events three of which strongly affected patterns of sedimentation. First, at the end of the Ordovician, glacio-eustatic sea level fall drained the platform and caused a break in sedimentation. Melting of glaciers, accompanied by sea level rise in the early Silurian (Yarenej time), returned deposition to the carbonate platform of the basin. Rapid deepening of the basin continued up to early Lolashor time (Fig. 3). Second, in the late Llandovery (Filipp"el' time) for the first time, and then in the Wenlock (late Ust'Durnayu time) and Ludlow 
(Padimejtyvis and Sizim times), the east-dipping ramp was converted to a rimmed shelf with reefs on its outer margin, and with slumps, debris-flows and turbidites on the newly formed slope. The third event was a gradual regression on the platform, which began in the late Silurian with short-term transgressions in Tselebej and Ust'Syv'yu times and culminated during the Early Devonian. The above general tendencies in sea level changes in the Timan-northern Ural region correlate in general with the global sea level curve (Fig. 3). Most probably, the differences between the two curves resulted from some regional tectonic events causing spreading and subduction processes associated with the Pechora Plate (Yudin \& Dedeev 1987; Malyshev 1994), but some inadequate datings of strata cannot be excluded either.

\section{ACKNOWLEDGEMENT}

The author is grateful to the reviewers M. E. Johnson and D. Kaljo for helpful comments on the paper.

\section{REFERENCES}

Antoshkina, A. I. 1988. The Lower Palaeozoic reefal complexes of the Subpolar Urals. In Litologiya karbonatnykh porod severa Urala, Paj-Khoya $i$ Timana (Eliseev, A. I. \& Yudovich, Ya. E., eds.). Tr. In-ta geol. Komi nauch. tsentra UrO AN SSSR, 67, 22-31 (in Russian).

Antoshkina, A. I. 1994. Rify v paleozoe Pechorskogo Urala. Nauka, St. Petersburg (in Russian).

Antoshkina, A. I. \& Beznosova, T. M. 1976. Lithological-facies peculiarities of the Silurian Greben' Stage of the northern Pre-Urals. In Geologiya i poleznye iskopaemye SeveroVostoka evropejskoj chasti SSSR: (Ezhegodnik-1975) (Fishman, M. V., ed.), pp. 14-19. Syktyvkar (in Russian).

Antoshkina, A. I. \& Beznosova, T. M. 1981. Stratigraphical position of the upper Silurian organic buildups in the northern part of the Urals. In Stratigrafiya paleozoya severo-vostoka Evropejskoj chasti SSSR. Tr. In-ta geol. Komi filiala AN SSSR, 37, 3-15 (in Russian).

Antoshkina, A. I. \& Beznosova, T. M. 1987. About connections between the evolutionary stages of the upper Ashgill to Silurian biota and sedimentary cycles. In Stratigrafiya $i$ paleoekologiya paleozoya $i$ kajnozoya Severo-Vostoka evropejskoj chasti SSSR (Tsyganko, V. S., Chermnykh, V. A. \& Borintseva, N. A., eds.). Tr. In-ta geol. Komi filiala AN SSSR, 62, 4-16 (in Russian).

Antoshkina, A. I. \& Beznosova, T. M. 1999. The Llandovery-Wenlock boundary in the Urals. In Geologiya $i$ mineral'nye resursy evropejskogo severo-vostoka Rossii: novye rezul'taty $i$ novye perspektivy. Materialy XIII Geologicheckogo s"ezda Respubliki Komi, Vol. II (Yushkin, N. P., ed.), pp. 187-189. Inst. geol. Komi nauch. tsentra UrO RAN, Syktyvkar (in Russian).

Antoshkina, A. I., Pershina, A. I., Borintseva, N. A. \& Filippova, L. I. 1976. Silurian of the TimanUral region. In Trudy VIII geologicheskoj konferentsii Komi ASSR, Vol. II, pp. 18-24. Syktyvkar (in Russian).

Antoshkina, A. I., Afanas'ev, A. K. \& Beznosova, T. M. 1989. A new Upper Ordovician and Silurian stratigraphical scheme of the northern part of the Urals (Eletskaya zone). Ser. preprintov nauch. dokladov Komi nauch. tsentra UrO AN SSSR, 206, 1-16 (in Russian). 
Antsygin, N. Ya., Popov, B. A. \& Chuvashov, B. I. (eds.). 1993. Stratigraficheskie skhemy Urala. IGiG UNTs RAN, Ekaterinburg (in Russian).

Belyakova, L. T. 1988. Stratigraphical subdivisions of the Izhma-Omra complex. In Stratigrafiya $i$ litologia neftegazonosnykh otlozhenij Timano-Pechorskoj provintsii (Bogatskij, V. I., Belyakova, L. T., Dzabarova, V. V., Eremenko, V. I. \& Pankratov, Yu. A., eds.), pp. 1721. VNIGRI, Leningrad (in Russian).

Berry, W. B. N. \& Boucot, A. J. 1970. Correlation of the North American Silurian rocks. Geol. Soc. Am. Spec. Pap., 102.

Beznosova, T. M. 1985. New early Silurian brachiopods from the northeastern part of the European USSR. In Raschlenenie $i$ korrelyatsiya fanerozojskikh otlozhenij evropejskogo Severa SSSR. Tr. In-ta geol. Komi filiala AN SSSR, 54, 3-16 (in Russian).

Beznosova, T. M. 1994. Biostratigrafiya i brakhiopody silura Evropejskogo severo-vostoka Rossii. Nauka, St. Petersburg (in Russian).

Beznosova, T. M. 2000. Silurian brachiopods in the Timan-northern Ural region: zonation and palaeoecology. Proc. Estonian Acad. Sci. Geol., 49, 126-146.

Filippova, L. I. 1973. Facies zones in the Silurian carbonate deposits of the eastern Timan-Pechora province. In Tezisy vtorogo soveshchaniya komiteta po osadochnym porodam 15-21 maya 1973 (Majsheva, Yu. I. \& Polievskaya, G. A., eds.), pp. 36-38. VSEGEI, LeningradTallinn (in Russian).

Johnson, M. E., Kaljo, D. \& Rong, J.-Y. 1991. Silurian eustasy. In The Murchison Symposium (Bassett, M. G., Lane, P. D. \& Edwards, D., eds.). Spec. Pap. Palaeontol, 44, 145-163.

Kaljo, D. L. (ed.). 1987. Resheniya mezhvedomstvennogo stratigraficheskogo soveshchaniya po ordoviku $i$ siluru Vostochno-Evropejskoj platformy 1984 g. s regional'nymi stratigraficheskimi skhemami. Izd. VSEGEI, Leningrad (in Russian).

Koren, T. N. 1964. Silurian Graptolites of the Polar Urals and Their Stratigraphical Significance. Avtoreferat dissertatsii kandidata geologo-mineralogicheskikh nauk, VSEGEI, Leningrad (in Russian).

Majdl', T. V. 1987. Peculiarities of the composition of carbonate reservoirs in the Ordovician-lower Devonian oil-gas-bearing complex. In Pechorskij neftegazonosnyj bassejn. Tr. In-ta geol. Komi filiala AN SSSR, 61, 17-28 (in Russian).

Malyshev, N. A. 1994. Geodynamic regime of the formation and development of the sedimentary basins in the northern part of European Russia. In Geologiya $i$ mineral'no-syr'evye resursy Evropejskogo severo-vostoka Rossii: Tezisy XII Vserossijskoj geologicheskoj konferentsii, Vol. III (Yushkin, N. P. \& Pystin, A. M., eds.), pp. 212-215. Syktyvkar (in Russian).

Männik, P., Antoshkina, A. I. \& Beznosova, T. M. 2000. The Llandovery-Wenlock boundary in the Russian Arctic. Proc. Estonian Acad. Sci. Geol., 49, 104-111.

Martynov, A. V. \& Mel'nikov, S. V. 1993. Ordovician-Silurian boundary in the Timan-Pechora province. In Paleontologicheskij metod v geologii, pp. 24-28. IGiRGI, Moscow (in Russian).

Modzalevskaya, T. L. 1981. Late Silurian and early Devonian brachiopods in the Subpolar Urals and Chernyshev Uplift. In Ezhegodnik VPO, Vol. XXIV (Modzalevskaya, E. A. \& Kolobova, I. M., eds.), pp. 173-204. Nauka, Leningrad (in Russian).

Modzalevskaya, T. L. \& Beznosova, T. M. 1992. Some Silurian Spiriferidae from the Pechora Urals and Soviet Arctic islands. In Fanerozoj evropejskogo severa Rossii. Tr. In-ta geol. Komi nauch. tsentra UrO RAN, 75, 4-16 (in Russian).

Nestor, H. 1987. Explanations to the stratigraphical schemes of the Silurian strata. In Resheniya mezhvedomstvennogo stratigraficheskogo soveshchaniya po ordoviku i siluru VostochnoEvropejskoj platformy 1984 g. s regional'nymi stratigraficheskimi skhemami (Kaljo, D. L., ed.), pp. 58-112. Izd. VSEGEI, Leningrad (in Russian).

Pershina, A. I. 1962. Silurian and Devonian Deposits of the Chernyshev Uplift. Academy of Sciences, Leningrad-Moscow (in Russian). 
Pershina, A. I., Tsyganko, V. S., Shcherbakov, E. S. \& Borintseva, N. A. 1971. Biostratigraphy of the Silurian and Devonian Deposits of the Pechora Urals. Nauka, Leningrad (in Russian).

Puchkov, V. N. 1993. Paleooceanic structures in the Urals. Geotektonika, 3, 18-33 (in Russian).

Savelieva, G. N. \& Nesbitt, R. W. 1996. A synthesis of the stratigraphic and tectonic setting of the Uralian ophiolites. J. Geol. Soc. London, 153, 525-537.

Tsyganko, V.S. \& Chermnykh, V. A. (eds.). 1983. Opornye razrezy pogranichnykh otlozhenij silura $i$ devona Pripolyarnogo Urala. Inst. geol. Komi filiala Akad. nauk SSSR, Syktyvkar (in Russian).

Tsyganko, V. S. \& Chermnykh, V. A. (eds.). 1987. Opornye razrezy verkhnego ordovika i nizhnego silura Pripolyarnogo Urala. Inst. geol. Komi filiala Akad. nauk SSSR, Syktyvkar (in Russian).

Valiukevičius, J. J., Gladkovskij, V. T., Karatajūtè-Talimaa, V. N., Kuršs, V. M., Mel'nikov, S. V. \& Menner, V. VI. 1983. Silurian and Lower Devonian stratigraphy of the northern Timan. Izv. AN SSSR, ser. geol., 10, 53-64 (in Russian).

Vojnovskij-Kriger, K. G. 1945. Two Palaeozoic complexes on the western slope of the Polar Urals. J. Sov. Geol., 6, 27-44 (in Russian).

Yudin, V. V. \& Dedeev, V. A. 1987. Geodynamical model of the Pechora Plate. Ser. preprintov nauch. dokladov Komi nauch. tsentra UrO AN SSSR, 171, 1-22 (in Russian).

Zonenshain, L. P., Kuzmin, M. I. \& Natapov, L. M. 1990. Geology of the USSR: a plate-tectonic synthesis. Am. Geophys. Union Geodynamic Series, 21.

\section{SILUR TIMAANI-UURALI PÕHJAOSA PIIRKONNAS}

\section{Anna ANTOŠKINA}

Siluris kujunes Baltika paleokontinendi kirdeosa šelfil välja ulatuslik karbonaatne platvorm. Settimine toimus siin väga mitmekesistes, valdavalt madalaveelistes (laguun, tõusu-mõõna tasandik, suletud šelf, riff, avašelf) tingimustes. Regiooni siluri läbilõikeid iseloomustab rikkalik fossiilide kooslus.

Timaani ja Uurali põhjaosa settebasseini arengus ilmneb selgesti kolm põhisündmust.

1. Hilisordoviitsiumi jäätumisest tingitud meretaseme langus põhjustas settimise katkemise peaaegu kogu platvormil. Liustike kiire sulamisega varasiluris kaasnev transgressioon taastas piirkonnas settimise alles Jarenei eal.

2. Esmakordselt Filippjeli (Hilis-Llandovery) eal, seejärel aga ka Ust-Durnaju (Wenlock) ja Ludlow' eal isoleerisid platvormi idaserval arenevad rifivööndid Timaani-Uurali basseini peaaegu täielikult avaookeanist. Neil ajavahemikel toimus settimine platvormil valdavalt suletud šelfi tingimustes. Riffide-eelset nõlva iseloomustasid aga sagedased settevoolud, mis kandsid basseini sügavamasse ossa purdset materjali.

3. Siluriajastu lõppu iseloomustas pidev, üha süvenev regressioon, mis saavutas maksimumi varadevonis.

Timaani-Uurali põhjaosa regioonis fikseeritud siluri mere taseme kõikumised korreleeruvad hästi globaalse eustaatilise kõveraga. 


\section{СИЛУР ТИМАНО-СЕВЕРОУРАЛЬСКОГО РЕГИОНА}

\section{Анна И. АНТОШКИНА}

В силуре на северо-восточном шельфе палеоконтинента Балтика сформировалась обширная карбонатная платформа. Осадки на ней, представленные фациями лагун, приливно-отливных равнин, закрытого и открытого шельфа и рифов, как правило, были богаты разнообразными органическими остатками. В седиментационной модели наиболее четко отражены три события. Первое - почти полное отсутствие седиментации на большей части платформы, обнажившейся в результате гляциоэвстатического понижения уровня моря в конце ордовика. Резкое таяние ледников в раннем силуре восстановило осадконакопление на платформе в яренейское время. Второе событие связано с тем, что сначала в филиппъельское время (поздний лландовери), а затем в устьдурнаюское время (венлок) и в лудлове наклоненный на восток карбонатный рамп конвертировался в обрамленный шельф с рифами на его внешней окраине и с дебрисными потоками и турбидитами на новообразованном склоне. Третьим важным событием в истории силурийского бассейна была устойчивая регрессия, начавшаяся в позднем силуре и кульминационно проявившаяся в раннем девоне. Кривая колебаний уровня силурийского моря в Тимано-Североуральском регионе показывает совпадение событий с глобальной кривой на границах ордовика и силура, горстиана и лудфордия, внутри лудфордия и в позднем теличии. 